УДК 352.07

DOI https://doi.org/10.32836/2310-9653-2020-3.15

І. М. Безена, кандидат фрілософрьких наук, доцент, завідувач кафедри соціально-гуманітарної освіти КЗВО «Дніпровська академія неперервної освіти» Дніпропетровської обласної ради, докторант Дніпропетровського регіонального інституту державного управління Національної академії державного управління при Президентові України

\title{
НОВІ МЕХАНІЗМИ ДІЯЛЬНОСТІ ДЕРЖАВНОГО УПРАВЛІННЯ ТА ІНСТИТУТІВ ГРОМАДЯНСЬКОГО СУСПІЛЬСТВА В КОНТЕКСТАХ СТРАТЕГІЙ РОЗВИТКУ ОСВІТНЬОЇ СФЕРИ РЕГІОНУ
}

Стаття присвячена дослідженню нових механізмів державного управління та інститутів громадянського суспільства у процесах демократизациї і децентралізащії публічної влади та контекстах становлення стратегій розвитку освітньої сфери регіону. У ході прочесів реформи актуалізуються практики залучення громадськості до організаиійних проиесів формування та практичної реалізачії державної політики у сфері освіти. Як свідчить зарубіжний досвід, ключовими питаннями постають: єдність і міщність суспільних цінностей та суспільних інституцій; дотримання основ демократії у механізмах залучення громадян/громадянських інституиій до проиесів врядування на території громади; суттєвий вплив суб'єктів громадянського суспільства на процеси сталого розвитку громади та прав і свобод людини, в тому числі на освіту.

У дослідженні проаналізовано сучасні практичні і початкові результати спільної діяльності у Дніпропетровському регіоні, механізми долучення інститутів громадянського суспільства до реформування освітньої сфери суспільства з метою підвищення задоволення потреби особистості в доступності до мережі закладів $і$ якості освіти. Ключовим змістовим питанням практик організаційної діяльності держсвного управління регіонального рівня є конструктивна співпраця з органами місиевого самоврядування, громадськими інституиіями території та жителями сіл $і$ міст. Актуалізуються процеси реалізаиії інфраструктурних проєктів території, які спрямовано на покращення освітнього середовища та інтерактивного простору для інтелектуального розвитку людини. Адже мережа і зміст освіти визначають стратегічні орієнтири 6 людському розвитку території. Від рівня їхньої ефективної і спільної роботи залежать перспективи розвитку території $i$ бюджетне наповнення, якість життя громади, інвестиційна привабливість громади і благополуччя ії громадян.

За результатами дослідження встановлено, що від рівня співпраці державного управління, місцевого самоврядування і громадського активу громади, стратегічно вибудованих партнерських стосунків, організачійного розвитку взаємної довіри і відповідальності буде залежсти динамізм розвитку території та освітньої сфери, розв'язання критичних соиіальноекономічних проблем і поступ у розвитку регіону. Сучасні регіональні практики підтверджують актуальність для стратегії розвитку території, наявність активних і професійних суб'єктів організаційної діяльності для послідовної реалізації інфраструктурних та організаційних процесів: аналіз ситуації, планування, обговорення, прийняття рімення, бюджетування проєктів та їх ефективна реалізація і успішність регіону.

Ключові слова: Стратегія розвитку, сталий розвиток, партнерство, взаємодія, освітня система.

I. M. Bezena. New mechanisms of public administration and civil society institutions in the contexts of educational development strategies

The article is devoted to the study about new mechanisms of public administration and civil society institutions in the processes of democratization and decentralization of public power and the contexts of formation of strategies for the education development in the region. During the reform processes, the public involvement practices in the organizational and formation processes, as well as practical implementation of state policy in the field of education are actualized. According to foreign experience, the key issues are: the unity and strength of social values and social institutions; adherence to the foundations of democracy in the mechanisms of citizens / civic institutions involvement in the processes of governance in the community; significant influence of civil society actors on the processes of sustainable community development and human rights and freedoms, including education.

The study analyzes current practical and initial results of joint activities in the Dnipropetrovsk region, mechanisms for involving civil society institutions in reforming the educational sphere of society in order to increase the individual's need for access to the institutions network and the quality of education. The key substantive issue concerning organizational activities of public administration at the regional level is constructive cooperation with local governments, public institutions and residents of villages and towns. The processes of infrastructural projects realization in the territory, which are aimed at improving the educational environment and interactive space for intellectual development, are being updated. After all, the network and content of education determine the strategic guidelines for human development. The prospects of development of the territory and budget content, quality of life of the community, investment attractiveness of the community and the well-being of its citizens depend on the level of the educational network's effective and joint work.

(C) I. М. Безена, 2020 
The study found that the level of cooperation between public administration, local government and community, strategically built partnerships, organizational development of mutual trust and responsibility will depend on the dynamism of the territory and educational sphere development, solving critical socio-economic problems and progress in development of the region. Modern regional practices confirm the relevance for the development strategy of the territory, the presence of active and professional subjects of organizational activities for the infrastructural and organizational processes and their consistent implementation: situation analysis, planning, discussion, decision-making, project budgeting and their effective implementation and the region's success.

Key words: development strategy; sustainability; partnership; interaction; educational system.

Постановка проблеми. Публічні інституції українського суспільства перебувають у стані трансформації, які проходять відповідно до стратегічних потреб у підвищенні ефективного розвитку суспільства. Сучасні структурні зміни органів місцевої влади та тенденції у сприянні розвитку активних суспільних інституцій місцевої громади вже досягнуто певних позитивних результатів з демократизації громадянського простору. Події останніх років в цивілізованих країнах світу, національному та регіональному просторі підтверджують актуальність таких структурних змін, які проходять 3 перспективою поглиблення демократичних процесів, розширення сфер для взаємної співпраці, долучення, прозорості і підвищення довір'я між суспільними інститутами - державної влади та громадянськими об'єднаннями. Освітня сфера в окреслених контекстах займає особливе місце, яке визначається її особливими завданнями, спрямованими на формування громадянина освіченого, справедливого, відповідального, толерантного, системного і спроможного долати життєві проблеми. Конструктив взаємин «влада-людина» завжди є актуальним і визначальним у процесах людського розвитку, сталого і ефективного просування до суспільних ідеалів організації та успішної життєдіяльності.

Наразі перед суспільними інституціями і суспільством постають актуальними питання про те, що є основою мотивації до консолідації адміністративних територій та громадян, місцевого самоврядування та органів влади. Виходячи з окресленого, можна відмітити такі концепти: підвищення ролі ефективних механізмів місцевої самоорганізації через конструктивну співпрацю влади та громадських інститутів, окремих громадян через долучення їх до організаційних процесів стратегічного розвитку і змін життєвого й освітнього простору. Відповідно, актуалізується значення процесів, які спрямовано на підвищення стандартів життя, якості й доступності до освіти, вирішення спільних соціально-економічних проблем людського розвитку, формування інвестиційної привабливості місцевої громади та позитивні зміни через реалізацію стратегічних інфраструктурних проектів.

Аналіз останніх досліджень і публікацій. Дослідження проблем спільної діяльності публічної влади і громадянських інституцій та пошуку нових механізмів організаційної діяльності в розвитку громадянського суспільства в Україні знаходить своє дослідження в науковому середовищі. Бердавова О., Вакуленка В., Гринчука Н., Колтуна В., Куйбіди В., Серьогіна С., Бородіна С., Сиченка В., Шевченко Н., Романенко К., Кулєшова О., Дмитренка К., ін. досліджують окремі аспекти теорії і практичних процесів демократизації в державно-громадському управлінні та організаційній діяльності громади з вибудовування нових стратегій розвитку соціально-освітньої сфери території регіону. Зарубіжні дослідження окреслених наукових і практичних аспектів розпочалися раніше, оскільки європейські країни вже пройшли нові рівні етапів демократизації та децентралізації, тепер вони можуть поділитись власним досвідом із налагодження нових ефективних моделей стратегії розвитку політичної системи, влади об’єднаних громадах та державно-громадського управління в соціально-економічній сфері регіонів.

Мета статті. У дослідженні буде проаналізовано стан формування нових механізмів державно-громадського партнерства на регіональному рівні у стратегіях ефективних змін в системі освіти.

Виклад основного матеріалу. Одним із ключових викликів сучасного національного простору і його публічних інституцій постали: недовіра до влади, від центру до регіону, ефективності організаційної діяльності її посадовців, відчуження людини від процесів управління громади та негативні настрої в середовищі окремих груп громадян. Виходячи з окресленого, стратегія розвитку регіону, нової громади та їі публічного управління має визначатися демократичною розбудовою сучасного громадянського суспільства. Проте в сучасних практиках ефективним результатом діяльності всіх інституцій суспільства постають питання «активних, динамічних і позитивних змін» в соціальних життєвій діяльності, яка спрямована на покращення рівня життя громадян, «долучення жителів до громадсько-активної співпраці із органами місцевої влади у вирішення проблем території» [1, с. 199]. Ключовою проблемою в окресленому аспекті постає питання щодо розвитку суб'єктів громадянського суспільства, які будуть брати на себе повну відповідальність за організаційні і комунікативні лінії діяльності, яка, крім всього, взаємозбалансована в публічному просторі місцевої громади. Адже будь-яка суспільна діяльність спрямована на отримання достовірної інформації про рівень ефективності організаційних заходів та сталий розвиток громади і людини. Процес управління сучасною системою освіти громади вже не може зосереджуватися тільки на процесі управління, а й досягнення комунікативних функцій із метою досягнення суспільно значимого результату у сталому розвитку освітньої сфери.

У Національній доповіді «Цілі Сталого Розвитку: Україна» (далі - ЦСР) викладено бачення стратегічних орієнтирів, досягнення яких визначено принципом «нікого не залишити осторонь» через використання широкого кола інформаційних, статистичних та аналітичних матеріалів у контексті «держава-громадянин» й реалізації 86 завдань 
для зростання людини, громади, держави. Серед ЦСР визначено 17 ключових векторів: подолання бідності; подолання голоду, розвиток сільського господарства; міцне здоров'я і благополуччя; якісна освіта; гендерна рівність; чиста вода та належні санітарні умови; доступна та чиста енергія; гідна праця та економічне зростання; промисловість, інновації та інфраструктура; скорочення нерівності; сталий розвиток міст і громад; відповідальне споживання та виробництво; пом'якшення наслідків зміни клімату; збереження морських ресурсів; захист та відновлення екосистеми суші; мир, справедливість та сильні інститути; партнерство заради сталого розвитку [2, с. 2, 3, 34].

Процес реалізації ЦСР орієнтує держави й суспільства на постійний змістовний моніторинг та вимірювання суспільних процесів, удосконалення системи національної статистики, перетворення механізмів планування організаційної діяльності через розвиток соціального партнерства в громаді. До четвертої ЦСР - «якісна освіта», включаються такі завдання: забезпечення доступності до якісної шкільної освіти для всіх дітей та підлітків; забезпечення доступності до якісного дошкільного розвитку для всіх дітей; забезпечення доступності до професійної освіти; підвищення якості вищої освіти та забезпечення ії тісного зв’язку з наукою, сприяння формуванню в країні міст освіти і науки; збільшення поширеності серед населення знань і навичок, необхідних для отримання гідної роботи та підприємницької діяльності; ліквідація гендерної нерівності серед шкільних учителів; створення у школах сучасних умов для навчання, включаючи інклюзивне, на основі інноваційних підходів. Основою процесів забезпечення якісної освіти постає рівний доступ до неї й поєднання з п’ятьма векторами: якість, справедливість, доступність, залучення та всебічне заохочення [2, с. 36]. Не заперечно, що окреслені очікування будуть реальністю лише завдяки тісній співпраці державних та громадських інституцій, органів управління й самоврядування. А окреслені аспекти трансформуються в контексті нових перспектив завершення організаційного формування територій і органів місцевого самоврядування (далі - ОМС) громад Дніпропетровської та інших регіонів України й перегляду змісту системи освіти нових адміністративних територій [3].

Необхідно розглянути, яка склалась модель процесу управління освітою, адже класично окреслюють наступні чотири етапи: 1) визначення мети діяльності; 2) моделювання (прогнозування, планування); 3) організація і регулювання можливих управлінських впливів на систему освіти (визначення потенціалів та ризиків ситуаціі); 4) аналіз процесів та контроль ситуації і досягнення ефективних результатів. Відповідно, до сутності процесу управління відносимо: цілеспрямований вплив на систему освіти (в межах визначених повноважень), який окреслюється системною цілеспрямованістю, організаційною діяльністю, регуляторними процедурами, постійною аналітичною роботою та можливостями коригування процесів. Окреслені управлінські впливи визначають громадську оцінку ефективності діяльності органу влади та його посадовців з трьох сторін: перша, що робиться або іiі зміст; друга, організаційна ситуація (хто, коли і порядок дій); третє, технологія процесу (як здійснюється та процедури). Усі окреслені сторони є рівнозначними за змістом, визначають ефективність стратегій та раціональну ефективність процесів для людського розвитку.

Проведені дослідження серед жителів громади показали певні проблеми у відкритості, прозорості та комунікативній дії сучасних органів самоврядування, а саме: кожен другий респондент відзначив відсутність інформації про сучасні стратегії розвитку території; кожен третій відмітив нерозуміння проблемної ситуації та можливих управлінських дій ОМС; кожен другий не розуміє межі відповідальності ОМС та регіональних органів державної влади; кожен другий не розуміє механізми для того, щоб його думку почули і врахували, та місцеві громадянські інституції, які можуть їх об’єднувати; кожен другий не готовий до особистої участі у вирішенні суспільних/ громадських проблем. Сучасні практики діяльності ОМС свідчать про актуальність даного питання та стратегію поглиблення демократичних процесів на рівні місцевої/регіональної влади. Окреслена місцева ситуація свідчить про проблеми з комунікативною дією ОМС, яка може привести до поглиблення розриву між ОМС та жителями громади [4; 5]. Таким чином, новим ОМС необхідно розвивати нові та актуальні механізми співпраці 3 громадянськими інституціями для розширення комунікації та залучення їх до стратегічних процесів діяльності, спрямованої на вирішення місцевих соціально-економічних проблем.

У сучасній системі управління освіти можна окреслити такі різні концепти перспективи і стратегії розвитку освітньої системи: 1) централізована модель освітніх стандартів, яка не надає можливості розвиватись академічній свободі та автономії освітньої системи громади; 2) відсутність регуляторного врахування регіональних потреб на зміст освіти та збереження етнокультурної спільноти громадян; 3 ) управління освіти на основі авторитарних тенденції та обмеження процесів пошуку нових авторських моделей та індивідуалізації освіти людини; 4) нав'язування надмірної одноманітності форм менеджменту, недооцінка особливостей регіонального освітнього простору та механізмів організаційної діяльності управління освіти. Виходячи з викладеного, ми відмічаємо, що однією із ключових моделей пошуку постає питання щодо розбудови нових механізмів державно-громадського управління освітою через суб’єкти організаційної діяльності - владу, громадськість та врядування.

Звичайно, найпоширеніші форми залучення громадських інституцій і громадян проходять за такими принципами, як: батьківська рада, громадська рада з питань освіти, спостережна рада, звіти перед громадою 3 питання розвитку і якості надання освітніх послуг, розміщення на цифрових носіях публічної інформації з освітньої діяльності. Але і в окреслених формах є значна кількість вад, формалізму, імітації, закритості розгляду, непублічності 
та непослідовності. Таким чином, не заперечно, що інформаційне забезпечення має формуватися на основних принципах: інтенсифікації інформаційних процесів (терміни, періодичність, зміст); єдності інформаційного забезпечення (професійність, послідовність, комплексність, чесність, прозорість, об'єктивність, консультування, обговорення); відповідності інформації суб'єкту повноважень (адресність аналізу, організаційне реагування, ефективність дії); оптимальності інформації (оцінка реального стану, систематичність, пропозиції).

Для демократичного управління в освіті та розвитку дієвого громадянського суспільства з огляду на окреслене постають основні питання щодо нового рівня взаємовідносин публічної влади і громадськості, які у правовій державі окреслюються процедурами в обмеженні і невтручанні в діяльність громадянських інституцій, регламентації консультативної з ними діяльності. Відповідно, ефективні взаємовідносини мають будуватися в усіх сферах суспільної діяльності - економічній, соціальній, освітній, екологічній, духовній, етнічній, релігійній тощо. Основною організаційною проблемою в розвитку конструктивної взаємодії органів публічної влади та громадськості в регіоні постають такі питання, як: ефективна і прозора реалізація державної політики, комунікативна дія всіх учасників процесу; послідовна і системна публічна діяльність у протидії порушенням норм правовідносин, забезпечення дотримання прав людини та попередження проявів корупції; забезпечення демократичних принципів врядування й участі в реальних процесах, консультування і впливу на організаційну діяльність громади, громадянських інститутів та громадян; всебічний розвиток територіальних громад та інфраструктури освіти через сталий суспільний простір, призначений для освіченої і суспільно-активної особистості [6].

Як показує сучасний досвід організаційної діяльності нових територіальних громад регіону, найчастіше громадські інституції та органи публічної влади об'єднують питання розвитку і подолання проблем громади, а це, відповідно: стан водопостачання населених пунктів і системи освіти; енергоефективність та технічний стан будівель інфраструктури і закладів освіти; проблеми з кадровим забезпеченням інфраструктури і системи освіти; розвиток мережі соціальної інфраструктури громади та закладів освіти; запровадження інклюзивного навчання дітей та врахування запитів на вивчення мов національних меншин; підтримка соціально-вразливих категорій населення; розширення пропозицій щодо освітніх послуг для жителів громади; розвиток нових форм освіти через запровадження очно-дистанційного, дистанційного або інтегрованого навчання; осучаснення ресурсного забезпечення освітнього простору; вибудовування різних моделей державно-громадського управління в освіті; прозорість та відкритість у змісті освітньої діяльності тощо. 3'являються нові форми взаємодії: громадське обговорення проблем, консультативна експертиза, оприлюднення проектів та їх змісту, долучення до процесів реалізації проєктів, звітування про їх реалізацію тощо.

Прикладом ефективного державно-громадського партнерства слугує конструктивна співпраця публічних та громадянський інституцій у сфері проєктного менеджменту, який направляється на створення ефективних механізмів для створення оптимальної моделі інфраструктури громади [7]. Так, одним із нових векторів роботи $\epsilon$ долучення OMC та громадськості до соціальних інфраструктурних програм U-Lead в Україні. Передусім, у 2019 році розпочато системну роботу із залучення до формування стратегічних інфраструктурних проєктів місцевих громад і громадських організацій, та було подано 240 пакетів документів на отримання зовнішніх інвестиції у регіональні/місцеві програми: інвесторами виступили державний, обласний і місцевий бюджети, громадські інституції, суб'єкти господарювання регіону та іноземні структури.

Необхідно відзначити, що більше 60\% інфраструктурних проєктів складають нові стратегії з осучаснення і розвитку ресурсної бази закладів освіти регіону. Окреслені управлінські та організаційні процеси є реальним свідченням конструктивного/ефективного підходу до вирішення місцевих соціально-економічних проблем всіх суб'єктів співробітництва громади, яке спрямовано на покращення якості життя та діяльності людини. Таким чином, практичними прикладами організаційної діяльності впроваджується сучасний режим державного управління «пост-New Public management», основою якого постають такі питання, як: конкуренція ідей та діяльності; забезпечення збалансованості приватних прав; акцент на лідерство та сервісні організації; контроль, оцінка і аудит процесу; регулювання бюрократичної поведінки; генерування кращих і результативних ідей та діяльності; обмеження впливу держави на методи/моделі управління в регіоні; центр суспільної уваги є громадяни і їхні освітні та інші запити.

Отже, ми відзначаємо особливу суспільну вагу індикаторів кількісних оцінок сталого розвитку території у співставленні із європейськими практиками, якими є: рівень самодостатності бюджету; збалансована економічна інфраструктура; транспортна інфраструктура; розвиток соціальної стабільності та забезпечення справедливості у доступності до якісної освіти; порівняльні характеристики соціально-економічної рівності міст та сільської місцевості (модернізація комунікативних зв'язків, зменшення негативного впливу на довкілля, збереження культурної спадщини території, збалансованість розвитку, політика регіональної згуртованості, інклюзивне зростання можливостей людини, соціальний прогрес); м’які трансформації неіндустріальних територій тощо [5, с. 640].

В умовах активних процесів демократизації і децентралізації значно посилюється значення вимірів політичної свободи, рівності політико-правового контролю за публічними інститутами, розвитку дефіцитної демократії й ключового значення людського фактору, демократичних процедур і комунікативних систем для формування потенціалів сталого розвитку регіону [8, с. 640]. Одним із сучасних ключових каналів комунікації постають цифрові мережі, які мають як вади, так і позитивні тенденції інформування: оприлюднення рішень та обговорення проєктів рішень; 
винесення на громадську експертизу проблеми території та шляхи їх вирішення; обговорення ситуацій на публічних зібраннях громадського активу (вулиця, село, квартал, селище, місто). Це лише окремі приклади, які реалізуються в регіонах, з метою розширити моделі долучення до суспільних справ громадян та громадянських інституцій до питання розвитку освітньої системи регіону. Не викликає жодних сумнівів, що ключовими питаннями в діяльності регіональної влади та громадянських інститутів постають: моніторинг суспільної думки щодо процесів в освітній системі громади; пошуки конструктивної співпраці влади і громади, яка спрямована на сталий розвитку громади; відпрацювання механізмів співпраці з подолання кризових явищ та стратегії поступального розвитку громади.

Висновки $з$ дослідження і перспективи подальших розвідок у цьому напрямі. Таким чином, регіональними результатами теоретичної та практичної управлінської діяльності, спрямованої на демократизацію та децентралізацію суспільного простору, окреслюються нові механізми і стратегії розвитку конструктивної співпраці з громадянськими інститутами: 1) визначено стратегії та пріоритетні механізми розвитку активних інституцій громадянського суспільства, подолання стану дефіциту демократії, вибудовування нової матриці місцевої демократії, які стають основою для сталого розвитку громад, розвитку системи освіти регіону; 2) проводиться розвиток нових комунікативних та організаційних механізмів громадської участі у процесах врегулювання освітніх запитів місцевого значення, які спрямовано на формування ефективної демократичної системи врядування, публічного і державно-громадського управління соціально-економічним розвитком регіону; 3) формується новий рівень розвитку моделей місцевої демократії, просвітницької роботи, місцевої самоорганізації та підвищення активності населення, що стали основою становлення доброчесного, організованого й активного врядування; 4) місцевий досвід колективної і комунікативної дії у вирішенні ресурсного забезпечення освітнього простору постає основою ефективного розвитку громади, регіону і держави. За результатами дослідження окреслились проблеми для таких досліджень, як інтегровані механізми державного управління інноваційним розвитком освіти, регіональний аспект.

\section{Список використаних джерел:}

1. Бородін С.I., Безена I.М., Марк Е. Генсон про шляхи демократизації та децентралізації публічних інституцій держави. Публічне управління та митне адміністрування. Науковий збірник. 2019. № 3(22). 290 с.

2. Цілі Сталого Розвитку: Україна. Національна доповідь. 2017. URL : http://www.un.org.ua/ua/publikatsii-ta-zvity...

3. Перспективний план формування територій громад Дніпропетровської області. Розпорядження Кабінету Міністрів України від 20.05.2020 р. № 601-p. URL : https://zakon.rada.gov.ua.

4. Безена I.M. Управління стратегічним розвитком громади: публічна влада й інститути громадянського суспільства в умовах децентралізації. Право та державне управління. Збірник наукових праць. № 1 . Том 2. 2020. C. 223-229.

5. Akimova L.M., Khomiuk N.L., Bezena I.M., Lytvynchuk I.L., Petroye O.. Planning of Socio-economic Development of the Territories (Experience of European Union). International Journal of Management (IJM). Volume 11, Issue 4, April 2020, pp. 638-646.

6. Хабермас Ю. Постнациональная констелляция и будущее демократии / Перевод Б.М. Скуратова. Логос. 2003. № 4-5(39).

7. Національна стратегія розвитку освіти в Україні на період до 2021 року. Схвалено Указом Президента України від 25.06.2013 р. № 344/2013.

8. Empfohlene Zitierweise: Lauth, Hans-Joachim und Oliver Schlenkrich. 2020. Konzeption der Demokratiematrix. URL : file://D:/\%D0\%97\%D0\%B0\%D0\%B3\%D1\%80\%D1\%83\%D0\%B7\%D0\%BA\%D0\%B8/Konzeption_Demokratiematrix.pdf.

\section{References:}

1. Borodin Ye.I., Bezena I.M., (2019) Mark E.Henson pro shliakhy demokratyzatsii ta detsentralizatsii publichnykh instytutsii derzhavy [Mark E. Genson on Ways of Democratization and Decentralization of Public Institutions of the State]. Publichne upravlinnia ta mytne administruvannia. Naukovyi zbirnyk. 2019. № 3 (22). 290 s.

2. Tsili Staloho Rozvytku: Ukraina. Natsionalna dopovid. 2017. URL: http://www.un.org.ua/ua/publikatsii-ta-zvity...

3. Perspektyvnyi plan formuvannia terytorii hromad Dnipropetrovskoi oblasti. Rozporiadzhennia Kabinetu Ministriv Ukrainy vid 20.05.2020 r. № 601-r. URL: https://zakon.rada.gov.ua/laws/show/601-2020-\%D1\%80\#Text

4. Bezena I.M. Upravlinnia stratehichnym rozvytkom hromady: publichna vlada y instytuty hromadianskoho suspilstva v umovakh detsentralizatsii. Pravo ta derzhavne upravlinnia. Zbirnyk naukovykh prats. № 1. Tom 2. 2020. S. $223-229$.

5. Akimova L.M., Khomiuk N. L., Bezena I.M., Lytvynchuk I.L., Petroye O. Planning of Socio-economic Development of the Territories (Experience of European Union). International Journal of Management (IJM). Volume 11, Issue 4, April 2020, pp. 638-646.

6. Habermas J. (2005) Die Postnationale Konstellation und die Zukunft der Demokratie. Logos, № 4-5 (39), 2005. P. 105-145.

7. Natsionalna stratehiia rozvytku osvity v Ukraini na period do 2021 roku. Skhvaleno Ukazom Prezydenta Ukrainy vid 25.06.2013 r. № 344/2013.

8. Empfohlene Zitierweise: Lauth, Hans-Joachim und Oliver Schlenkrich. 2020. Konzeption der Demokratiematrix. URL: file://D:/\%D0\%97\%D0\%B0\%D0\%B3\%D1\%80\%D1\%83\%D0\%B7\%D0\%BA\%D0\%B8/Konzeption_Demokratiematrix.pdf 